\title{
Petrology, magnetostratigraphy and geochronology of the Miocene volcaniclastic Tepoztlán Formation: implications for the initiation of the Transmexican Volcanic Belt (Central Mexico)
}

\author{
Nils Lenhardt • Harald Böhnel • Klaus Wemmer • \\ Ignacio S. Torres-Alvarado • Jens Hornung • \\ Matthias Hinderer
}

Received: 23 October 2009/Accepted: 23 February 2010/Published online: 9 April 2010

(C) Springer-Verlag 2010

\begin{abstract}
The volcaniclastic Tepoztlán Formation (TF) represents an important rock record to unravel the early evolution of the Transmexican Volcanic Belt (TMVB). Here, a depositional model together with a chronostratigraphy of this Formation is presented, based on detailed field observations together with new geochronological, paleomagnetic, and petrological data. The TF consists predominantly of deposits from pyroclastic density currents and extensive epiclastic products such as tuffaceous sandstones, conglomerates and
\end{abstract}

Editorial responsibility: H. Delgado Granados

Electronic supplementary material The online version of this article (doi:10.1007/s00445-010-0361-z) contains supplementary material, which is available to authorized users.

N. Lenhardt $\cdot$ J. Hornung $\cdot$ M. Hinderer Institut für Angewandte Geowissenschaften,

Technische Universität Darmstadt,

Darmstadt, Germany

H. Böhnel

Centro de Geociencias,

Universidad Nacional Autónoma de México,

Querétaro, Mexico

K. Wemmer

Geowissenschaftliches Zentrum Göttingen,

Göttingen, Germany

I. S. Torres-Alvarado

Departamento de Sistemas Energéticos, Centro de Investigación

en Energía, Universidad Nacional Autónoma de México,

Temixco, Mexico

N. Lenhardt $(\bowtie)$

Department of Geology, University of Pretoria,

Pretoria 0002, South Africa

e-mail: nils.lenhardt@up.ac.za breccias, originating from fluvial and mass flow processes, respectively. Within these sediments fall deposits and lavas are sparsely intercalated. The clastic material is almost exclusively of volcanic origin, ranging in composition from andesite to rhyolite. Thick gravity-driven deposits and largescale alluvial fan environments document the buildup of steep volcanic edifices. $\mathrm{K}-\mathrm{Ar}$ and $\mathrm{Ar}-\mathrm{Ar}$ dates, in addition to eight magnetostratigraphic sections and lithological correlations served to construct a chronostratigraphy for the entire Tepoztlán Formation. Correlation of the $577 \mathrm{~m}$ composite magnetostratigraphic section with the Cande and Kent (1995) Geomagnetic Polarity Time Scale (GPTS) suggests that this section represents the time intervall $22.8-18.8 \mathrm{Ma}$ (6Bn.1n-5Er; Aquitanian-Burdigalian, Lower Miocene). This correlation implies a deposition of the TF predating the extensive effusive activity in the TMVB at $12 \mathrm{Ma}$ and is therefore interpreted to represent its initial phase with predominantly explosive activity. Additionally, three subdivisions of the TF were established, according to the dominant mode of deposition: (1) the fluvial dominated Malinalco Member (22.8-22.2 Ma), (2) the volcanic dominated San Andrés Member (22.2-21.3 Ma) and (3) the mass flow dominated Tepozteco Member (21.3-18.8 Ma).

Keywords Magnetostratigraphy $\cdot \mathrm{K}-\mathrm{Ar}$ Geochronology · Volcaniclastics · Miocene - Tepoztlán Formation .

Transmexican Volcanic Belt $\cdot$ Central Mexico

\section{Introduction}

The transition of magmatism from the Sierra Madre Occidental to the TMVB has been discussed extensively during the last several decades (e.g., Mooser 1972; Demant 
1978; Cantagrel and Robin 1979; Nixon et al. 1987). Recent studies have shown that the TMVB, as a distinctive geologic province, dates back to the Middle to Late Miocene, as a result of a counterclockwise rotation of the magmatic arc of the Sierra Madre Occidental (Ferrari et al. 1999). Little is known about the initial activity of the early arc because the main focus of previous studies was on younger volcanism (Márquez et al. 1999; Siebe et al. 2004; García-Palomo et al. 2002; Verma 2000; Riggs and Carrasco-Núnez 2004). The remnants of the ancestral TMVB are found close to the present volcanic front of the central sector of the arc as stated by several authors, such as in the Sierra de Mil Cumbres and Sierra de Angangueo volcanic complexes in the State of Michoacán (Pasquaré et al. 1991; Capra et al. 1997) and in the Malinalco area (State of México), where lavas were dated at 19.5 Ma (Ferrari et al. 2003) and $21 \mathrm{Ma}$ (García-Palomo et al. 2000). These rocks are considered to be part of the initial Early Miocene activity of the Transmexican Volcanic Belt (Gómez-Tuena et al. 2007). Another piece of evidence of the early volcanic activity of the TMVB is the Tepoztlán Formation, which has been neglected so far in studies on the initial phase of the Transmexican Volcanic Belt.

The Tepoztlán Formation was mentioned first by Ordónez (1938) although the name was given much later by Fries (1960) and De Cserna et al. (1988), describing it briefly as "massive lahars rich in subrounded porphyritic andesite clasts intercalated with fluvial deposits". Furthermore, Fries assigned it as early Miocene in age, supposedly originating from the volcanic series of Mt. Xochitepec. Later, De Cserna and Fries (1981) suggested an origin from the volcanic centre of Zempoala in the State of México.

Haro-Estrop (1985) made the first attempt to establish a stratigraphical framework for the Tepoztlán Formation, dividing the formation into three different units based on the dominating depositional processes: a volcanic-laharic unit, a fluvial-laharic unit and a laharic-volcanic unit. Despite these works, it took several years until the first geological map of the Tepoztlán area was made by ÁvilaBravo (1998). In the same year, García-Palomo (1998) made a rough estimate of the age of the Tepoztlán Formation. K-Ar-geochronology of a basaltic andesite, which underlies the formation at San Nicolás near Malinalco, gave an age of $21.6 \pm 1.0 \mathrm{Ma}$, and a lava flow of the Basal Mafic Sequence on top of the formation an age of $7.5 \pm$ $0.4 \mathrm{Ma}$, thus confirming the formerly assumed depositional age within the Miocene (García-Palomo et al. 2000).

Prior to this study, direct radiometric ages and paleomagnetic studies were lacking and little was known about the depositional evolution of the Tepoztlán Formation. In the context of ongoing discussion on the initial activity of the TMVB, the Tepoztlán Formation represents one of the most important formations to decipher the evolution of this magmatic arc. Here, the chronostratigraphic framework of the Tepoztlán Formation is presented by means of a combination of a new K-Ar and Ar-Ar geochronology with paleomagnetic data as well as a description and interpretation of the major depositional units with a focus on their origin. The lithofacies of the studied rocks and depositional processes are examined and paleomagnetic and geochronological data are compiled to establish stratigraphic relationships. The combined results are used to provide an interpretation of the depositional regimes of the Tepoztlán Formation.

\section{Geological setting}

The TMVB is a continental magmatic arc that consists of nearly 8,000 volcanic structures (e.g., Gómez-Tuena et al. 2007). It was formed as a result of the subduction of the Cocos and Rivera plates under the North American plate along the Central American Trench, which was established during the Middle-Late Miocene (Ferrari et al. 2000). The TMVB is about $1,000 \mathrm{~km}$ long and ranges from 80 to $230 \mathrm{~km}$ in width. In contrast to other subduction-related volcanic belts, running parallel to a deep-sea trench, the TMVB is oriented in an E-W direction, forming an angle of ca. $16^{\circ}$ with the Middle America Trench (Gómez-Tuena et al. 2007). The belt consists of a large number of Tertiary and Quaternary cinder cones, maars, domes, and stratovolcanoes with predominantly calc-alkaline chemical and mineralogical composition (Siebe and Macías 2004).

The study area is located along the southern edge of the TMVB in the states of Morelos and Estado de Mexico (Fig. 1), where the Tertiary volcaniclastic series of the Tepoztlán Formation are covered by the Quaternary lavas and scoria of monogenetic volcanoes of the Chichinautzin volcanic field. The Tepoztlán Formation crops out in patches in an area of approximately $850 \mathrm{~km}^{2}\left(18^{\circ} 54^{\prime}-19^{\circ} 01^{\prime} \mathrm{N}\right.$ lat, $98^{\circ} 57^{\prime}-99^{\circ} 32^{\prime} \mathrm{W}$ long) and has an overall maximum thickness of $800 \mathrm{~m}$. The formation is widespread around the villages of Malinalco and Chalma in Mexico State and Tepoztlán and Tlayacapan in Morelos. Sparse outcrops are located east of Tlayacapan and southeast of the Nevado de Toluca (Capra and Macías 2000; García-Palomo et al. 2002).

A variety of Eocene-Oligocene (Balsas Group) and older rocks, mostly Cretaceous limestones, underlie the formation. It is covered by lava flows of Pliocene to Holocene age. Near Malinalco, the Tepoztlán Formation crops out between the San Nicolás Basaltic Andesite and the overlying Basal Mafic Sequence (García-Palomo et al. 2000). In Tepoztlán and the eastern vicinities it unconformably overlies the Balsas Group and is covered by the Chichinautzin Formation.

To the west of the city of Cuernavaca, the Tepoztlán Formation is partly covered by the ca. $150 \mathrm{~m}$ thick Cuernavaca Formation, which is similar in appearance to 


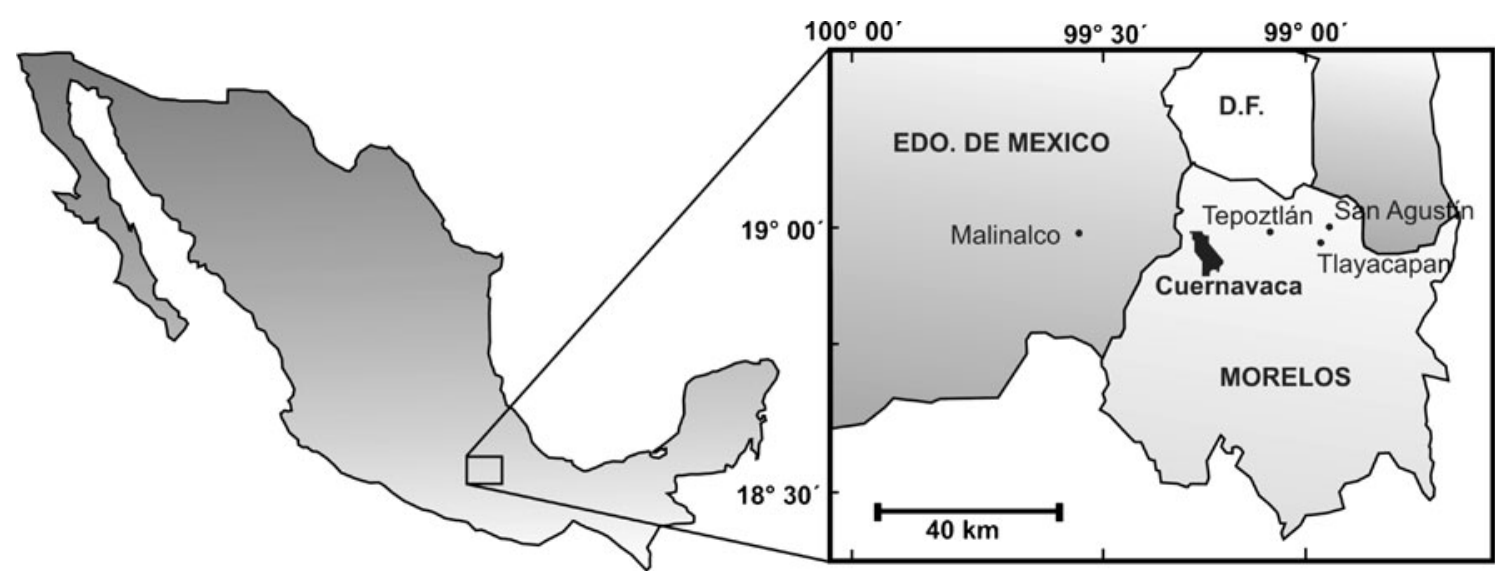

Fig. 1 Location of the study area

the TF and is characterized by alluvial fan deposits, emanating from the flanks of the Zempoala volcano to the south. According to Capra et al. (2002), the deposition of the Cuernavaca Formation was caused mainly by debris flows after the collapse of the SE-flank of the volcano. However, sedimentary structures within the deposits show that sheet flood and fluvial processes were also involved. The sediments are matrix-supported with clasts ranging from pebbles to blocks. The major part of the clasts possesses similar characteristics as the components of the Tepoztlán Formation but show signs of stronger alteration and a higher degree of rounding due to further transportation and re-deposition. To the north, clasts are dominated by the dark, vesicular lavas of the Zempoala volcano. To the south the clasts are dominated by eroded bedrock components of the Cretaceous Morelos Formation.

The Tepoztlán Formation is composed of calc-alkaline volcanic and sedimentary rocks. The volcanic rocks are predominantly of andesitic to dacitic composition, but also include rhyolites. The entire succession is composed of pyroclastic deposits (fall, surge and flow deposits), deposits from lahars (debris-flow and hyperconcentratedflow deposits) and coarse to fine fluvial and lacustrine deposits (conglomerates, sandstones and mudstones). Only a few lava flows and dykes are present. Bedding within the Tepoztlán Formation is generally flat-lying or gently dipping up to $10^{\circ}$ to $\mathrm{N} / \mathrm{NNE}$. The succession is disrupted by normal faults and intrusions of probably post-volcanic origin. Displacements at faults are frequently about half a meter and rarely exceed a few meters.

\section{Materials and methods}

Field work was carried out during several field campaigns within the states of Morelos and México ca. $70 \mathrm{~km}$ south of Mexico City in an area of approximately $1,000 \mathrm{~km}^{2}$. Eight stratigraphic sections, ranging in thickness from 78 to $378 \mathrm{~m}$, were logged and sampled for petrographical, sedimentological, geochemical and paleomagnetic analyses (Fig. 2). The sections provided a large and well-constrained sample suite covering all major depositional units and geological characteristics.

The Malinalco section (MAL) is located southeast of Malinalco $\left(18.93^{\circ} \mathrm{N}, 99.48^{\circ} \mathrm{W}\right)$. It is up to $93 \mathrm{~m}$ thick and is mainly composed of tuffaceous sandstones and tuffs with minor amounts of claystones and siltstones.

The San Andrés 1 section (SAN1) with a thickness of $183 \mathrm{~m}$ is located north of the San Andrés village $\left(18.95^{\circ} \mathrm{N}\right.$, $\left.99.11^{\circ} \mathrm{W}\right)$. The lower part of the section is dominated by tuffaceous sandstones and conglomerates and breccias resulting from fluvial and mass flow processes. With increasing altitude, more primary tuffs enter the system. The top of the section is dominated by primary tuffs and minor amounts of their reworked products in the form of fluvial and debris-flow deposits.

The San Andrés 2 section (SAN2; $18.58^{\circ} \mathrm{N}, 99.06^{\circ} \mathrm{W}$ ), $100 \mathrm{~m}$ east of SAN1, attains a thickness of $92 \mathrm{~m}$. The lower and the middle part are almost completely composed of tuffs, which can be correlated well with the corresponding strata in SAN1. Again, the top of the section shows an increase in fluvial deposits.

The Tepozteco section (TEP) is located to the north of Tepoztlán $\left(18.99^{\circ} \mathrm{N}, 99.10^{\circ} \mathrm{W}\right)$. The thickness of this section is $378 \mathrm{~m}$. The lower part is dominated by tuffaceous sandstones and conglomerates resulting from gravel bars and sandy channel fillings. Only minor amounts of primary volcanic material, deriving from pumice-and-ash and block-and-ash flows, can be recognized. The upper two-thirds of the section are dominated by the deposition of coarse tuffaceous breccias, i.e. debris-flow deposits resulting from lahars. Primary tuffs constitute only a minor amount in this part of the section. However, in the upper part, a thick lava flow can be found. The top of the section is composed 


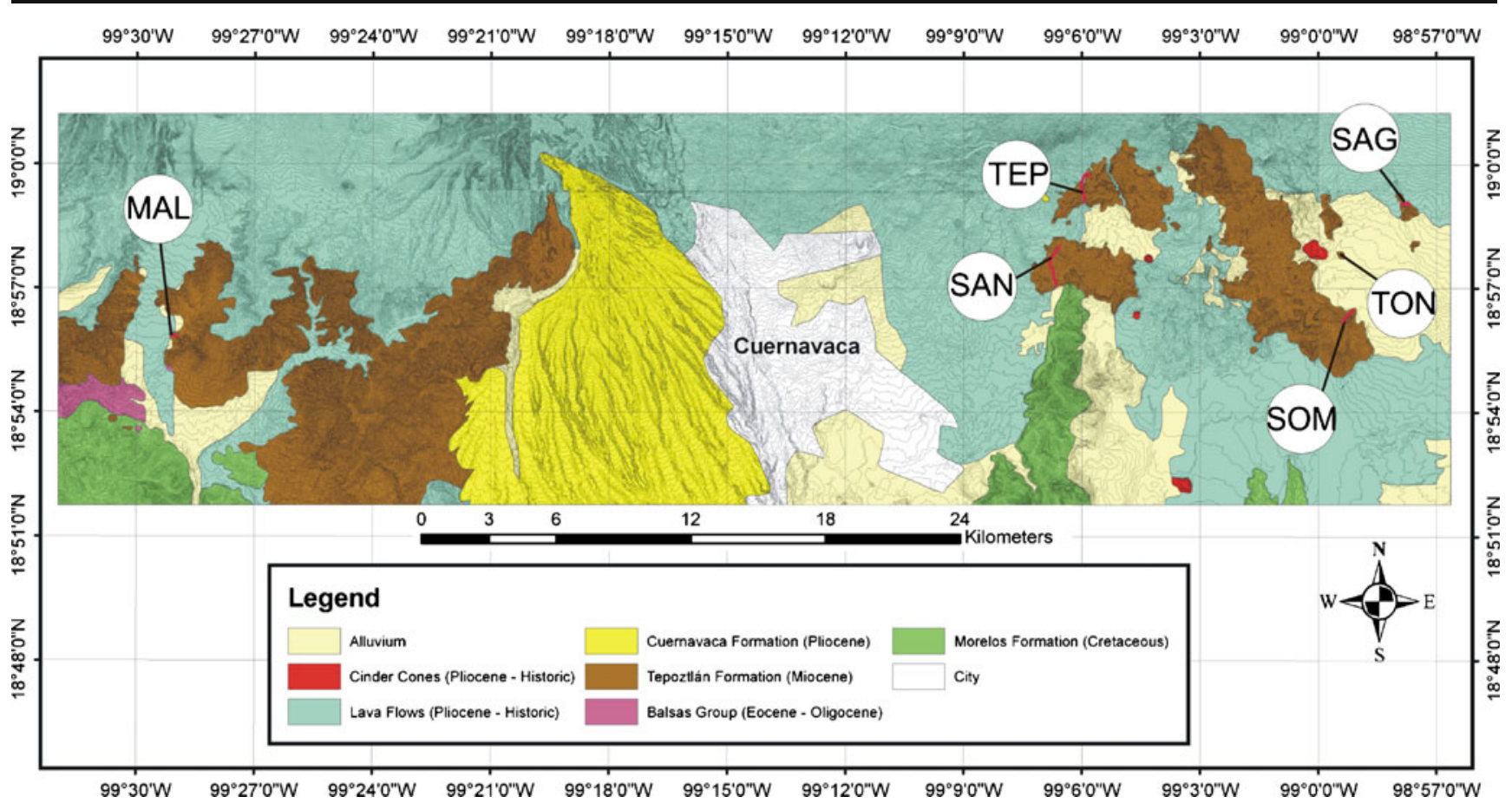

Fig. 2 Geological map with locations of the sampled sections (red lines). Outcrop locations are: MAL_Malinalco; TEP—Tepozteco; SAN—San Andrés; SOM-Cerro Sombrerito; TON—Cerro Tonantzin; SAG—San Agustín

primarily of debris-flow deposits with minor amounts of fluvial tuffaceous sandstones.

The Sombrerito 1 section (SOM1), southwest of Tlayacapan $\left(18.94^{\circ} \mathrm{N}, 98.98^{\circ} \mathrm{W}\right)$, is up to $78 \mathrm{~m}$ thick. The base of the section forms a thick lava flow with a thickening and coarsening upward sequence of tuffaceous sandstones and conglomerates and minor primary tuffs at the top.

The Sombrerito 2 section $\left(\mathrm{SOM} 2 ; 18.56^{\circ} \mathrm{N}, 98.59^{\circ} \mathrm{W}\right)$ is a continuation of SOM1 but with a horizontal shift of $100 \mathrm{~m}$ towards the northwest and attains a thickness of $110 \mathrm{~m}$. The lower part is composed mainly of primary volcanic products resulting from pumice-and-ash and block-and-ash flows. With increasing altitude, fluvial deposits become more dominant with increasing amounts of mass-flow deposits at the top.

The Tonantzin section (TON), in the north of Tlayacapan $\left(18.97^{\circ} \mathrm{N}, 98.98^{\circ} \mathrm{W}\right)$, has a thickness of $79 \mathrm{~m}$. Tuffaceous sandstones resulting from sheet floods and sandy channel fills dominate the lower part of the section. In the upper part, deposits from pumice-and-ash flows and debris flows are increasingly abundant.

The San Agustín section (SAG) is located to the northeast of Tlayacapan and to the north of San Agustín village $\left(18.99^{\circ} \mathrm{N}, 98.96^{\circ} \mathrm{W}\right)$. It attains a thickness of $133 \mathrm{~m}$ and is characterized by a steady increase in pyroclastic flow deposits. Deposits from debris flows are abundant, whereas fluvial tuffaceous sandstones and conglomerates decrease with increasing altitude within the section. The top of the section is characterized by a thick, blocky lava flow.

\section{Petrography and lithology of the Tepoztlán Formation}

Following the terminology for volcaniclastic rocks of McPhie et al. (1993), the Tepoztlán Formation is made up of tuffs and lavas, tuffaceous sandstones, conglomerates and breccias, originating as a result of different transportational and depositional processes during or after volcanic eruptions (Fig. 3). In order to assign each depositional unit to a certain mode of transport and deposition, their detailed petrography and lithologic description is given here. The modal proportions of phenocrysts are measured for nine representative samples of volcanic rocks (lava, blocks of block-and-ash flow deposits, lithoclasts of pyroclastic flow deposits) by point counting (Fig. 4; Table 1).

\section{Lava}

The lavas commonly have a blocky carapace and a dense core, due to exposure either on the top of mountain ridges or intercalated between other depositional units. All analyzed samples have a porphyritic to glomeroporphyritic texture. For the massive lavas, the total phenocryst content is $2-60$ vol.\%. Plagioclase is the most abundant phase with subordinate K-feldspar, clinopyroxene and amphibole. Accessory phases consist of mica, abundant titanomagnetite and other accessories.

The plagioclase phenocrysts of anorthitic composition $(\sim 2,500 \mu \mathrm{m})$ are euhedral to subhedral and show zonation. Clinopyroxene of augitic composition $(\sim 2,000 \mu \mathrm{m})$ is the 
Fig. 3 Photograph showing examples of different lithologies: a) lava, b) tuff, c) tuffaceous breccia, d) tuffaceous sandstones and conglomerates, e) tuffaceous silt- and claystones
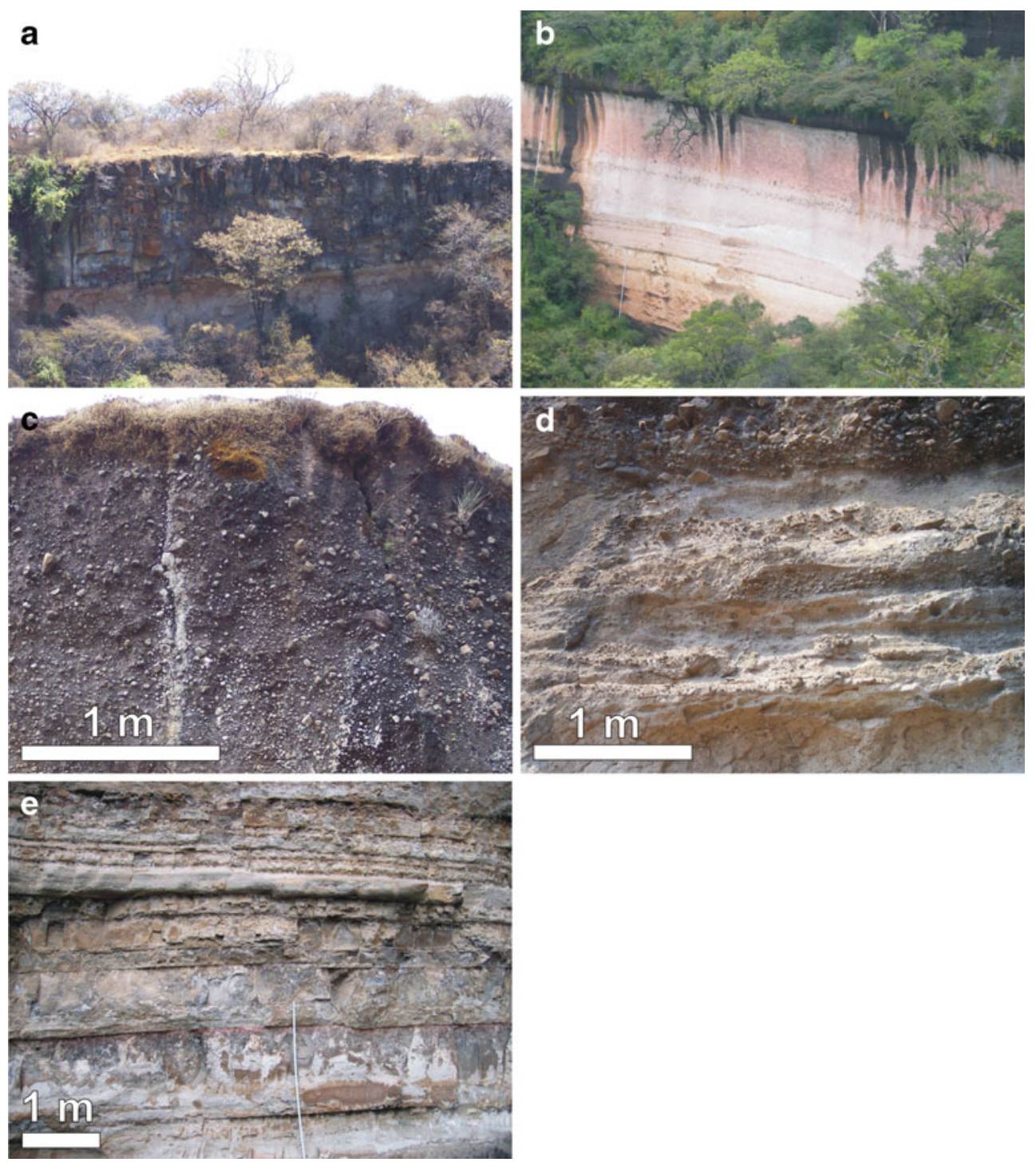

most abundant mafic phase and shows euhedral to subhedral habitus. Amphibole (magnesioriebeckite; $2000 \mu \mathrm{m}$ ) occurs as a minor constituent.

The groundmass shows a hyalophylitic, sometimes trachytic texture, comprised of plagioclase microlites and an ore phase (titanomagnetite). The whole-rock $\mathrm{SiO}_{2}$ content of the lavas ranges from 55.9 to $60.6 \mathrm{wt} . \%$, identifying them as andesites or dacites. With regard to its chemical composition, the depositional temperature for the lava is estimated to range between 800 and $1,200^{\circ} \mathrm{C}$ (Cas and Wright 1987).

\section{Tuff}

There are abundant exposed tuff layers within the study area. Each unit consists of a massive to finely laminated or cross-bedded, varicolored, poorly sorted mixture of medium to coarse ash horizons, sometimes rich in lapilli. Thickness ranges from a few centimeters to several meters.
Based on texture and lithology, fall and pyroclastic density current deposits can be distinguished. The fall deposits reach a thickness of up to $10 \mathrm{~cm}$, show mantle bedding and can be traced for several hundred meters throughout the outcrops. They consist of layers of coarse ash particles, showing either normal or inverse grading. The particles are composed of micropumice and pyroxene crystals.

The deposits of pyroclastic density currents can further be subdivided into units with stratification (ripples, crossbedding, and antidunes), massive pumice-rich units and blocky tuff breccia units with dense lava blocks. The depositional temperatures of pyroclastics are usually above $200^{\circ} \mathrm{C}$ (Fisher and Schmincke 1984). The upper boundary of the depositional temperatures is estimated to be below $400^{\circ} \mathrm{C}$, as the mineral content does not show any signs of modification due to welding (McArthur et al. 1998).

The stratified tuff layers range from 5 to $10 \mathrm{~cm}$ in thickness, are moderately sorted and are mostly composed of a coarse ash matrix with minor embedded pumice fragments. Locally, 
Fig. 4 Photomicrographs of volcanic rocks of the Tepoztlán Formation. Scale bar is $1 \mathrm{~mm}$, a) and $\mathbf{b})$ dense lava in the central part of a lava flow, c) and d) clasts in fluvial deposits, e) and f) tuff in non-polarized and polarized light
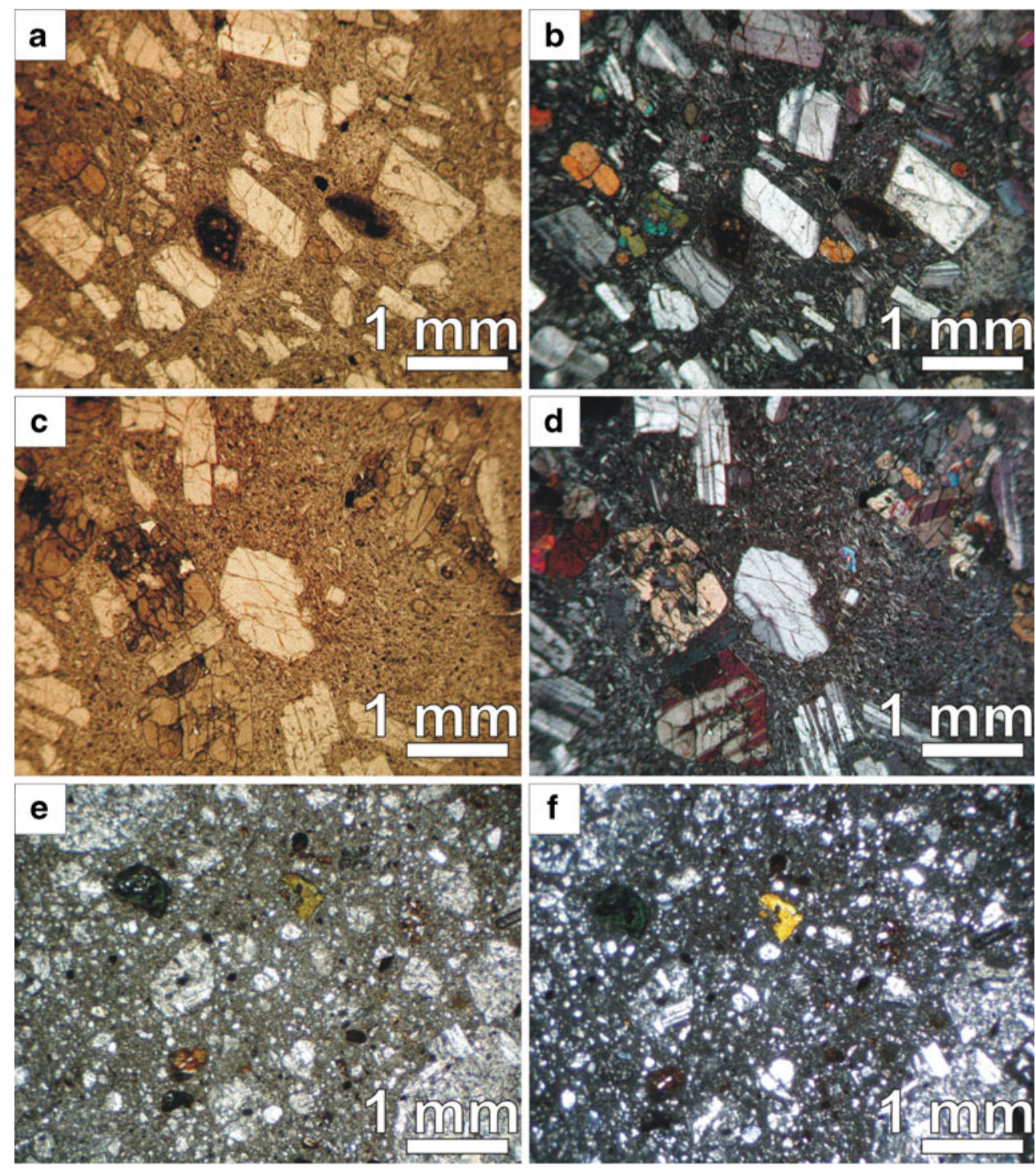

they show erosional bases and pinch-and-swell structures. They are interpreted as being deposited under surge-like depositional conditions from dilute gravity currents or during windy conditions (Allen et al. 1999).
The massive pumice-rich tuffs exhibit a wide range of grain-sizes from fine ash to cobble-sized lithic and pumice clasts (max. $10 \mathrm{~cm}$ ). The tuff matrix appears unwelded, composed of about $50 \%$ crystals, $2 \%$ lithics and $48 \%$ vitrics

Table 1 Modal abundance of representative samples of Tepoztlán Formation volcanic rocks in percent

\begin{tabular}{|c|c|c|c|c|c|c|c|c|c|}
\hline \multirow{2}{*}{$\begin{array}{l}\text { Lithology } \\
\text { Sample No. }\end{array}$} & \multicolumn{4}{|l|}{ Lava } & \multicolumn{2}{|c|}{ Blocks of block-and-ash flow } & \multicolumn{3}{|c|}{ Lithoclasts } \\
\hline & M210 & TL250-1 & TL233-12p & TE5 & TL233-HO & TL250-5p & SL1 & SL2 & SL3a \\
\hline Plag. & 40.40 & 0.68 & 15.74 & 0.36 & 2.52 & 5.84 & 1.12 & 4.08 & 17.10 \\
\hline K-fspar & 0.00 & 0.18 & 1.19 & 0.14 & 0.00 & 0.59 & 0.58 & 0.20 & 9.63 \\
\hline Amph & 5.94 & 0.00 & 0.00 & 0.02 & 0.15 & 1.58 & 0.98 & 1.29 & 0.55 \\
\hline Cpx & 13.07 & 0.88 & 11.88 & 1.47 & 0.30 & 1.88 & 0.00 & 0.20 & 2.45 \\
\hline Mica & 0.00 & 0.12 & 0.00 & 0.00 & 0.00 & 0.00 & 2.28 & 4.18 & 0.00 \\
\hline Quartz & 0.00 & 0.12 & 0.59 & 0.00 & 0.00 & 0.00 & 0.00 & 0.00 & 0.00 \\
\hline $\mathrm{Fe}-\mathrm{Ti}$ & 0.59 & 0.02 & 0.59 & 0.02 & 0.03 & 0.10 & 0.04 & 0.05 & 0.27 \\
\hline Groundmass & 40 & 98 & 70 & 98 & 97 & 90 & 95 & 90 & 70 \\
\hline
\end{tabular}

Plag. Plagioclase, K-fspar. K-feldspar, Amph. Amphibole, Cpx Clinopyroxene 
(average from 10 samples). Feldspar is the most dominant mineral phase. The crystals of plagioclase and K-feldspar are mostly broken and reach up to $2,500 \mu \mathrm{m}$ in size. Subordinate pyroxene (augite) ranges from 400 to $2,000 \mu \mathrm{m}$. Quartz crystals are a rare mineral phase but occur in three samples. Quartz microcrysts reach sizes of 200-500 $\mu \mathrm{m}$, while plagioclase microcrystals are commonly $40-120 \mu \mathrm{m}$ in size.

Cognate lithic clasts are composed of grey to red porphyritic rocks of dacitic to andesitic composition (58.5-66.5 vol.\% $\mathrm{SiO}_{2}$ ). Plagioclase crystals (up to $2 \mathrm{~mm}$ ) form the dominant mineral phase, accompanied by $\mathrm{K}$-feldspars (sanidine and microcline, $\sim 2 \mathrm{~mm}$ ). Subordinate minerals are amphibole (up to $2 \mathrm{~mm}$ ) and clinopyroxene (augite, $\sim 800 \mu \mathrm{m}$ ). Dark mica (biotite, $\sim 1 \mu \mathrm{mm}$ ) is present only in a few samples.

Pumice clasts range from creamy white to pale yellow in color. They are relatively dense to finely vesicular and usually porphyritic, containing predominantly augite and plagioclase as phenocrystals. Pumice clasts usually do not exceed diameters of $6 \mathrm{~mm}$ within the matrix. However, in pumice concentration zones, on top of single units, clasts can reach up to $10 \mathrm{~cm}$ in diameter. Due to transportation and abrasion they appear subrounded to rounded.

In some ignimbrites, rare accessory clasts were found, which originated in the subvolcanic basement, brought to the surface during the eruption. These consist of red claysiltstones and grey carbonate rocks. Under the microscope, the red clay-siltstone shows a proportion of $15 \%$ crystals in a clayey, in parts, still glassy matrix. The crystals consist of quartz, plagioclase and pyroxene as broken phenocrysts. Yellow, red and green particles suggest an alteration of pumice pieces. The appearance of the rock fragments points to an origin from the underlying Balsas Group.

The carbonates are light to dark grey in color. They are described as pack- or wackestones after Dunham (1962) with a calcitic-detritic matrix and supposedly originating from the underlying Morelos Formation. There are no macroscopic signs of fossil wood or other plant material. There are, however, microscopic fragments of charcoal and various palynomorphs (Lenhardt 2009).

The poorly sorted, blocky tuff breccia appears massive and matrix-supported. Grading patterns are absent. The angular, dense lava clasts are pre-dominantly block-sized, hexagonal-shaped and derived from columnar jointing in lava flows. These deposits are interpreted as block-and-ash flow deposits.

The clasts are of andesitic composition ( 59 vol.\% $\mathrm{SiO}_{2}$ ). The dominant mineral phase among the phenocrysts is plagioclase $(0.5-7 \mathrm{~mm})$ with amphibole $(0.1-4 \mathrm{~mm})$, augite $(0.1-4 \mathrm{~mm})$ and rare $\mathrm{K}$-feldspars $(0.5-5 \mathrm{~mm})$ as subordinate minerals. The groundmass is composed of plagioclase, Fe-Ti magnetites and abundant glass.
The matrix of the tuff breccia possesses a similar composition as the embodied lava clasts, pointing out to a co-genetic origin. It is made up of glass shards, lava fragments and abundant phenocrysts resembling the crystal content of the clasts.

\section{Tuffaceous breccias}

In association with the primary volcaniclastic deposits a wide variety of reworked products are found within the study area. Among them, the mass-flow deposits are characterized by tuffaceous breccias, originating from debris flows or hyperconcentrated flows. Debris-flow deposits are sheet-like, show no signs of grading or sorting and reach a thickness of up to $10 \mathrm{~m}$. The hyperconcentrated-flow deposits, however, show erosional basal surfaces, normal or inverse grading and occasionally diffuse sedimentary structures. These deposits reach approximately $4 \mathrm{~m}$ in thickness within the study area.

The mass-flow deposits are composed of angular to subangular clasts in a pinkish red matrix of fine to medium sand. The clast usually are pebbles and cobbles in size, not exceeding diameters of $20 \mathrm{~cm}$; however, single outsized clasts of $2 \mathrm{~m}$ in diameter were also observed. The clasts within the mass-flow deposits have similar characteristics and compositions as the primary deposits described above, suggesting an origin due to reworking of the latter. The prevalence of angular to subangular intermediate volcanic clasts implies a local source, and thus contemporaneous volcanism and sedimentation. The matrix of the mass-flow deposits is commonly composed of $30 \%$ lithic and pumice fragments (up to $1.2 \mathrm{~mm}$ ), $10 \%$ crystals and $60 \%$ glass shards, showing significant alteration to clay minerals. The fragments do not show any alignment within the matrix. Plagioclase $(600 \mu \mathrm{m})$ and amphibole $(800 \mu \mathrm{m})$ phenocrysts are subhedral and commonly broken while amphiboles show signs of alteration. The rare quartz phenocrysts reach sizes of up to $800 \mu \mathrm{m}$. The tuffaceous breccias were deposited under ambient air temperature conditions.

\section{Tuffaceous sandstones and conglomerates}

The grey, cross-bedded, fine- to medium-grained sandstones and pebbly to bouldery conglomerates within the study area are interpreted as fluvial deposits. They appear in sheets as manifested in channels and gravel bars or as lenses as a result of filling of scours. The matrix dominantly consists of sand grains, resembling small clasts of lava, pumice or reworked ash particles. Based on composition, presence of crystals and absence of basement material, the original fragmentation process and components support an initial pyroclastic origin. However, the sedimentary structures indicate significant reworking of either primary pyroclastic material or material previously reworked by 
lahars. Clast abrasion in streams was rather inefficient as shown by the subangular to subrounded shapes. The tuffaceous sandstones and conglomerates were deposited under ambient air temperature conditions.

Tuffaceous silt- and claystones

Several thin strata of red to purple tuffaceous siltstones and claystones are recognized within the study area. They appear massive or laminated and rarely exceed thicknesses of one or two cm. However, at some locations such as near Malinalco, silt- and claystones reach a thickness of several meters. Thin sheet- or lens-shaped deposits are interpreted as waning flood sediments. The purple color probably represents subaerial alteration. However, no paleosols were found throughout the whole sequence. Near Malinalco and in the east of the village of Santo Domingo in the State of Morelos $\left(19.00^{\circ} \mathrm{N}, 99.03^{\circ} \mathrm{W}\right)$, siltstones, which are several meters thick and coarsening-upward, are interpreted to be lacustrine deposits. This coarsening upward is thought to be a result of near-shore deposition with steady accumulation of sediment in a progradational setting. The tuffaceous siltand claystones were deposited under ambient air temperature conditions.

\section{Geochronology}

Sample selection/ sampling

The new ${ }^{40} \mathrm{~K} /{ }^{40} \mathrm{Ar}$ and ${ }^{40} \mathrm{Ar}{ }^{39} \mathrm{Ar}$ dates were obtaind for different dacitic to andesitic lava samples, collected within the sections TEP, SOM1 and SAG (TE5, SO14, TL250-5p, TL233-12p). Two more samples were taken close to MAL and SAN1 (M210, SAC) and their results were interpolated into the stratigraphic sections. Furthermore, one dyke (DY1) was sampled. The mineral contents of these samples are listed in Table 1.

\section{Analytical procedure for $\mathrm{K} / \mathrm{Ar}$ dating}

Samples were carefully cleaned and selected in order to avoid altered parts or veins. The selected pieces were broken and gently milled in a ball mill to reach a grain size of approx. $100 \mu \mathrm{m}$ to prevent the loss of Ar caused by the preparation.

The samples investigated suffer from a trapped atmospheric contamination (up to $90 \%$ of the ${ }^{40} \mathrm{Ar}$ ), which is unavoidable in most modern volcanic rocks (see discussion in McDougall and Harrison 1999). Therefore, errors amount to $15 \%(2 \sigma)$. Earlier Ar-Ar ages, published by Lenhardt (2004), were obtained from bulk rock analysis in a commercial laboratory.
The argon isotopic composition was measured in a pyrex glass extraction and purification line coupled to a VG 1200 $\mathrm{C}$ noble gas mass spectrometer operating in static mode. The amount of radiogenic ${ }^{40} \mathrm{Ar}$ was determined by an isotope dilution method using a highly enriched ${ }^{38} \mathrm{Ar}$ spike from Schumacher, Bern (Schumacher 1975). The spike is calibrated against the biotite standard HD-B1 (Fuhrmann et al. 1987). The age calculations are based on the constants recommended by the IUGS quoted in Steiger and Jäger (1977).

Potassium was determined in duplicate by flame photometry using an Eppendorf Elex 63/61. The samples were dissolved in a mixture of $\mathrm{HF}$ and $\mathrm{HNO}_{3}$ according to the technique of Heinrichs and Herrmann (1990). $\mathrm{CsCl}$ and $\mathrm{LiCl}$ were added as ionisation buffers and internal standards. The analytical error for the $\mathrm{K} / \mathrm{Ar}$ age calculations is given on a $95 \%$ confidence level $(2 \sigma)$. Details of Ar and $\mathrm{K}$ analyses for the laboratory in Göttingen are given in Wemmer (1991).

\section{Results}

The radiometric ages obtained (Tables 2 and 3) for the

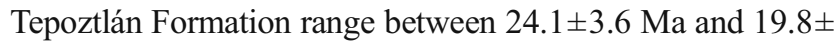
$0.8 \mathrm{Ma}$. This corresponds to the initial phase of the TMVB as stated by Gómez-Tuena et al. (2007). Because of the described errors, individual age dates are not significant. This shortcoming, however, can be counterbalanced by the correlation with the results from the paleomagnetic analysis and the lithology that follows.

\section{Paleomagnetic analysis}

Sampling

A total of 1087 cores were sampled from the described sections for this study, 174 in the MAL section, 236 in the two SAN sections, 171 in the TEP section, 289 in the two SOM sections, 64 in the TON section and 152 in the SAG section. Three to 12 cores were collected per horizon in average intervals of $10 \mathrm{~m}$. The samples were collected from tuffs, tuffaceous sandstones, the matrix of tuffaceous breccias and lava. While sampling sediments, zones with fine matrix were drilled to eliminate problems due to big grain sizes (e.g., Barberà et al. 2001). The most common way to extract drill cores is with the aid of a gasoline-driven drilling machine with diamond-studded drill heads. The diameter of the drill cores is usually $2.5 \mathrm{~cm}$ but drill cores with $1.2 \mathrm{~cm}$ diameter were also used. After drilling to a depth of $6-12 \mathrm{~cm}$, an orientation platform is slipped onto the sample while the latter is still attached to the surrounding rock. The orientation platform contains an 
Table 2 Data base of $\mathrm{K}-\mathrm{Ar}$ age determinations

\begin{tabular}{|c|c|c|c|c|c|c|c|}
\hline Sample & Spike [No.] & $\mathrm{K}_{2} \mathrm{O}$ [Wt. \%] & $40 \mathrm{Ar} *[\mathrm{nl} / \mathrm{g}] \mathrm{STP}$ & $40 \mathrm{Ar} *[\%]$ & Age $[\mathrm{Ma}]$ & $2 \delta$-Error $[\mathrm{Ma}]$ & $2 \delta$-Error [\%] \\
\hline M 210 & 3763 & 0.66 & 0.447 & 10.03 & 20.9 & 3.1 & 14.8 \\
\hline TE 5 & 3747 & 1.31 & 0.822 & 16.76 & 19.4 & 1.2 & 6.2 \\
\hline SO14 & 3752 & 0.74 & 0.557 & 6.62 & 24.1 & 3.6 & 14.9 \\
\hline TL 250-5p & 3759 & 1.16 & 0.752 & 20.91 & 20.0 & 1.0 & 5.0 \\
\hline TL 233-12p & 3743 & 1.33 & 0.853 & 28.48 & 19.8 & 0.1 & 0.4 \\
\hline
\end{tabular}

inclinometer to determine the inclination of the solid axle. It also contains a magnetic compass and a sun compass for the determination of the azimuths of the solid axle. The error of the directional reference is about $\pm 2^{\circ}$. After orientation, the drill core is labeled and taken to the laboratory for further treatment.

\section{Laboratory methods}

The natural remanent magnetization (NRM) of all samples was analyzed using an AGICO JR5 induction magnetometer. A total of 189 samples were demagnetized using a stepwise alternating field (AF) treatment in field amplitudes up to $100 \mathrm{mT}$ using an AGICO LDA instrument. Another 64 selected samples were thermally demagnetized using an ASC scientific model TD48 furnace. Remanence components were identified from orthogonal demagnetization plots (Zijderveld 1967) and best fits were determined using principle component analysis. Site mean directions were calculated using Fisher (1953) statistics (Table 4; electronic supplementary material).

Results

NRM intensities range between $0.00059 \mathrm{~A} / \mathrm{m}$ (lowest) and $81.16 \mathrm{~A} / \mathrm{m}$ (highest; average: $1.47 \mathrm{~A} / \mathrm{m}$ ). The ferromagnetic minerals within the samples are predominantly titanomagnetites with a relatively low content of titanium as previously observed during SEM studies (Lenhardt 2004) and from the AF and thermal demagnetization experiments.

Remanence acquisition for lava (depositional temperature above $600^{\circ} \mathrm{C}$ ) and tuff (depositional temperature between 200 and $400^{\circ} \mathrm{C}$ ) was through (partial) thermoremanent magnetization (TRM), and is acquired by a rock during cooling from a temperature above the Curie temperature in an external magnetic field (Merrill et al. 1998). Fluvial and mass-flow deposits (deposition at ambient air temperature) are characterized by detrital or depositional remanent magnetization (DRM), acquired by sediments when grains settle in water in the presence of an external magnetic field (Merrill et al. 1998).

Typical examples of AF demagnetization diagrams are shown in Fig. 5 as orthogonal projections of magnetization vectors. The NRM of the samples mainly consists of one dominating magnetization component with a small unstable contribution, which is removed during the first AF demagnetization steps $(0-20 \mathrm{mT})$. If more than two magnetization components were observed, then the characteristic direction was determined by taking into account the overall behavior of samples from the entire outcrop. All characteristic directions were defined using principal component analysis (Kirshvink 1983). The examples shown in Fig. 5 are from the main depositional environments, and the quality of the demagnetized data is clearly related to the temperature during deposition. The lava sample SO67-76 exhibits a strong univectorial thermoremanent magnetization component. All other samples, in comparison, are demagnetized faster at initial AF steps, and their directional behavior along the demagnetization process is also more dispersed. Nevertheless, in most cases a characteristic remanence direction may be determined with sufficient precision to assign a magnetic polarity.

These characteristic remanent magnetization directions were used to calculate site-mean directions and virtual geomagnetic poles (VGP). Often, the in-site dispersion of directions was large, with confidence limits $\alpha_{95}$ between $2.3^{\circ}$ and almost $90^{\circ}$. Large dispersion was related to large grain sizes of the sampled rock. It was also observed that

Table 3 Data base of Ar-Ar age determinations

\begin{tabular}{llcccrr}
\hline Sample & $\mathrm{J}$ & Weight $(\mathrm{mg})$ & MSWD & ${ }^{40} \mathrm{Ar} /{ }^{36} \mathrm{Ar}$ & $\%{ }^{39}$ Ar used & Age (Ma) \\
\hline SAC & $0.001020 \pm 0.000008$ & 124.0 & $0.18 / 2.63$ & $449.84 \pm 12.89$ & 61.7 & $21.86 \pm 0.20$ \\
DY1 & $0.001014 \pm 0.000010$ & 88.0 & $0.41 / 3.83$ & $319.32 \pm 16.3$ & 8.5 & $15.83 \pm 1.31$ \\
\hline
\end{tabular}

$J$ is the irradiation parameter, MSWD is the mean square weighted deviation (Wendt and Carl 1991), which expresses the goodness-of-fit of the isochron (Roddick 1978) 
(a) SO 1-13 (lava)

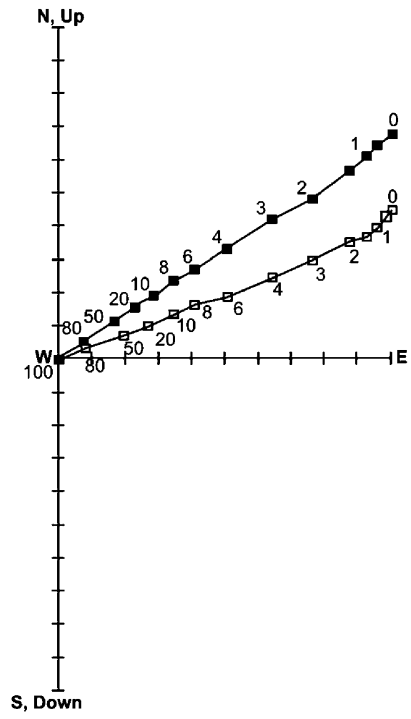

(b) CLV 1-7 (ash-flow deposit)

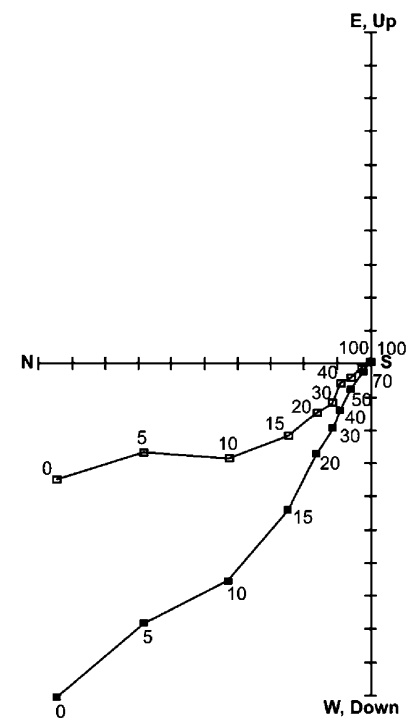

(a)
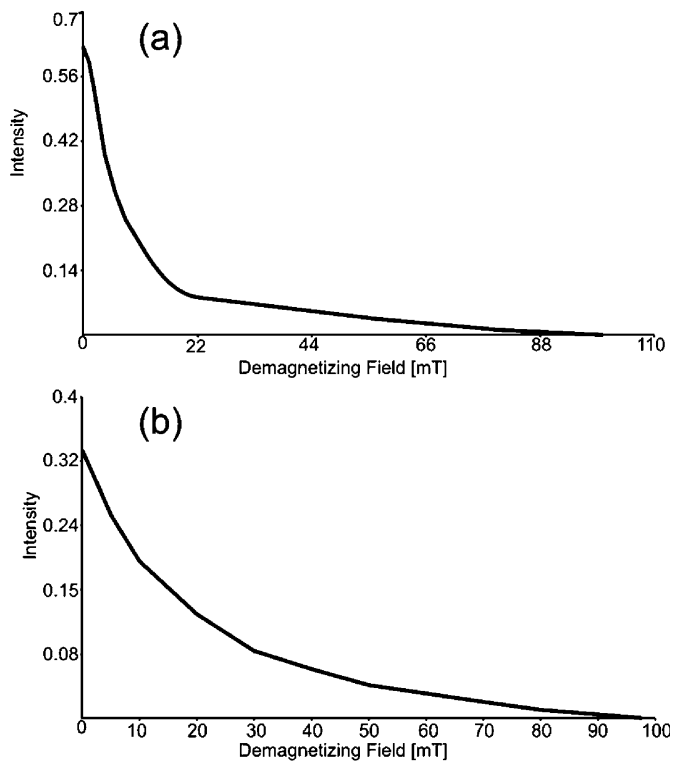

(c) T6-1 - 6-7 (debris-flow deposit)

(d) TL 58-64 (channel fill)
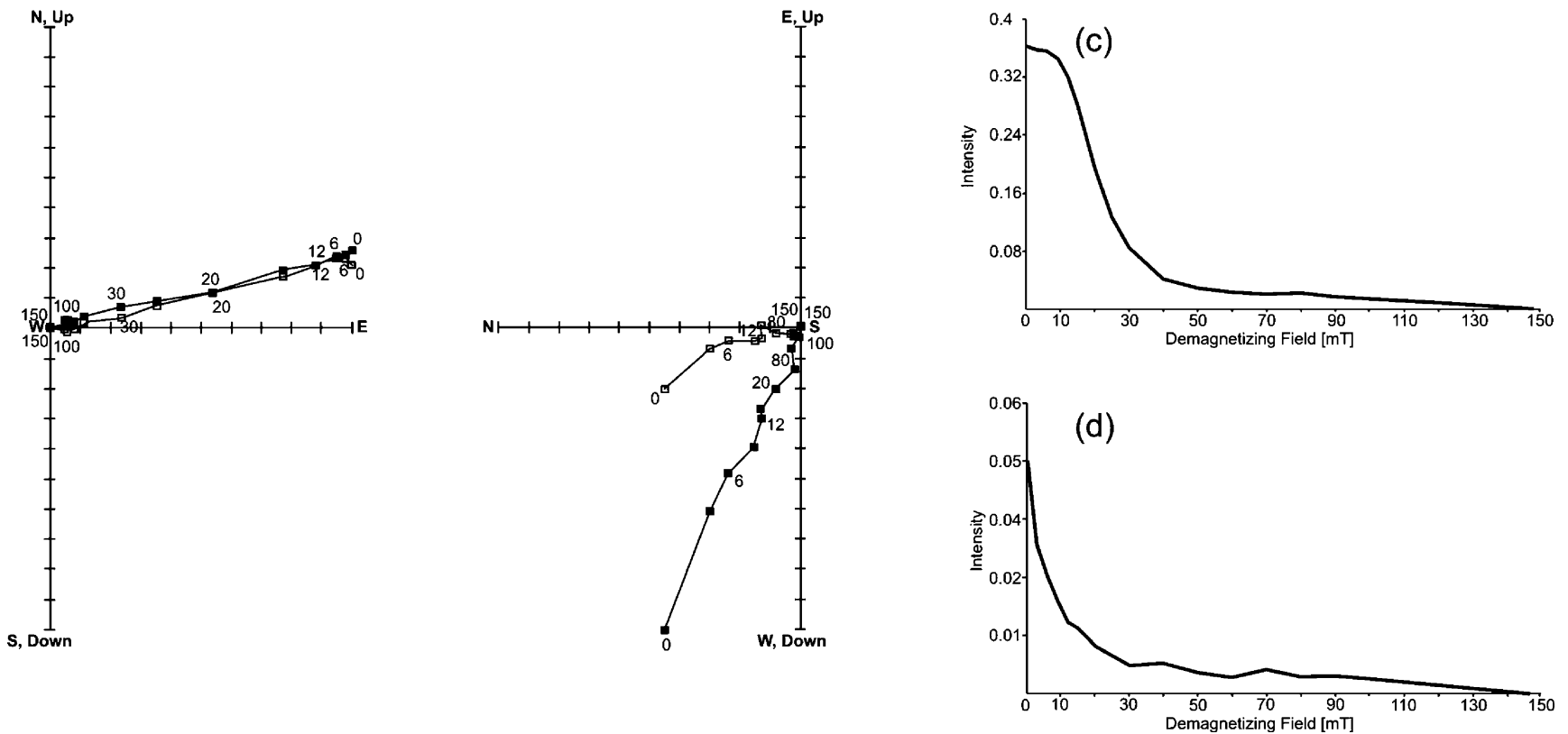

Fig. 5 Examples of orthogonal vector (Zijderfeld) plots of four samples undergoing alternating-field demagnetization. Each plot shows the projection of the magnetization vector endpoint on two perpendicular planes, one in the horizontal plane (solid symbols) and one vertical (open symbols). Numbers give strength of the demagnetizing field in milliTeslas (mT). To the right, intensity plots of the samples are shown

part of the samples showed well grouped magnetic directions, while several other samples showed clearly divergent and more random directions. This is interpreted to reflect the lateral and vertical variability within one sampling site of grain sizes and depositional processes involved, mainly in the fluvial sediments. Here, the inclusion of up to granule-sized particles, which are not oriented by the geomagnetic field, may produce a stable remanence direction deviating from the ambient field direction, which is not removable by demagnetization techniques. Site mean directions with confidence limits $\alpha_{95}$ higher than $40^{\circ}$ were thus considered as unconfined and were not subject to further analysis. Within the remaining samples, dispersion is lowest in lavas (mean $\alpha_{95} 9.7^{\circ}$ ) and highest in mass-flow deposits (mean $\alpha_{95}$ $21^{\circ}$ ). Fluvial deposits (mean $\alpha_{95} 17.5^{\circ}$ ) and tuffs (mean $\alpha_{95}$ $17.4^{\circ}$ ) have similar values, taken into account that the fluvial material mostly consists of reworked tuffs. 
Geomagnetic polarity was determined by the VGP latitude, being normal (reverse) for positive (negative) latitude. Sites with latitudes between $\pm 30^{\circ}$ were considered as intermediate and no polarity was assigned to them. Intermediate latitudes may have been produced by the geomagnetic field during excursions or reversals, but also tectonic processes like tilting of strata could have the same effect. According to field observations it can be assumed that tilting has not affected the studied rocks by more than $10^{\circ}$. In several places it is observed that intermediate directions are similar and occurred over several consecutive sites within the succession, while below and above directions were clearly reverse or normal, e.g. SO77 to SO126. This may suggest that these strata did not tilt and that the intermediate directions indeed may reflect shortlived but abnormal geomagnetic field conditions.

Comparison of the data before and after demagnetization shows that often the dispersion of the paleomagnetic data is enhanced by the treatment. Figure 6 shows examples for four sites of different lithologies, where the largest enhancement is seen in the case of lava flow SO1-13. Here, some samples were clearly affected by lightning-induced secondary magnetizations, which was probably due to the topographic exposure of this flow. These secondary components were effectively removed by the demagnetization process. Nevertheless, the polarity of magnetization did not change after the cleaning, and this is also the case in most other sites that were demagnetized, like pyroclastic flows TL28-33 and TL7, and the fluvial deposit TL 59-64 (Fig. 6). Therefore, it is assumed that the undemagnetized samples, producing reasonably well defined site mean NRM directions, may indeed be used for magnetostratigraphy purposes, a reasonable assumption based on detailed demagnetization experiments on about one-fourth of all recovered samples. In view of the large amount of samples collected and the time limitation associated with this study, only one sample per site for about three-fourth of the locations was demagnetized based on the general stable NRM directions. Major directional changes were not observed.

Figure 7 shows all site-mean directions that are not of intermediate polarity and that have an $\alpha_{95}<40^{\circ}$. There are 79 sites of normal/reverse polarity with a reasonably well defined antipodal distribution. This lends confidence to the assumption that these rocks indeed recorded the geomagnetic field during their deposition.

Local magnetic polarity stratigraphies (LMPS) were constructed for the individual sections, which are compiled into a single composite section covering a net of $\sim 577 \mathrm{~m}$ of
Fig. 6 Examples of equal area plots of paleomagnetic directions for different lithologies, before and after thermal and af demagnetization. Closed/open symbols define positive/negative inclinations, stars with ellipses the site-mean direction with $\alpha_{95}$ confidence limits

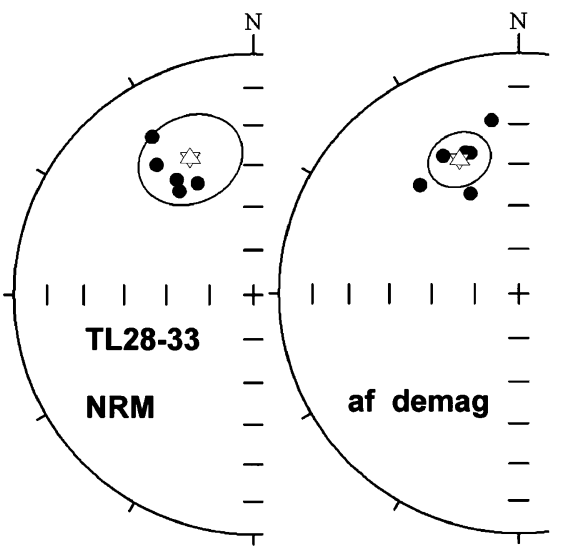

Ash-flow deposit

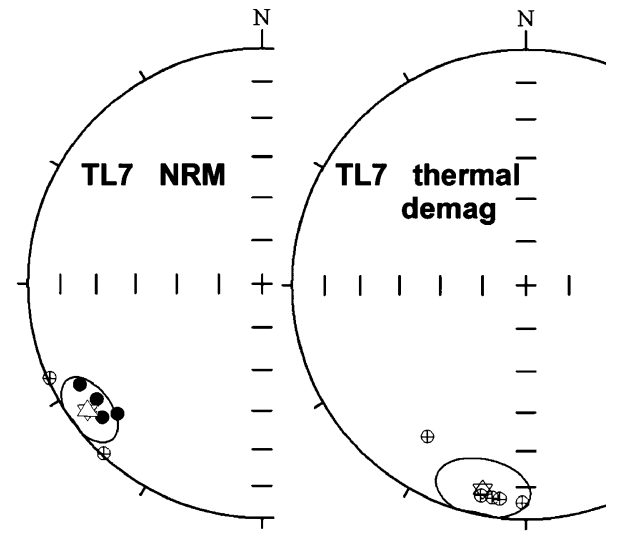

Ash-flow deposit

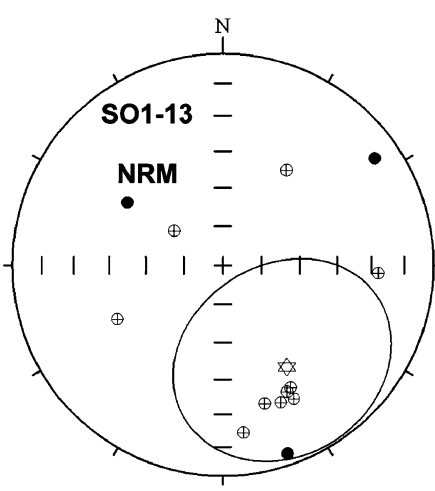

Lava flow
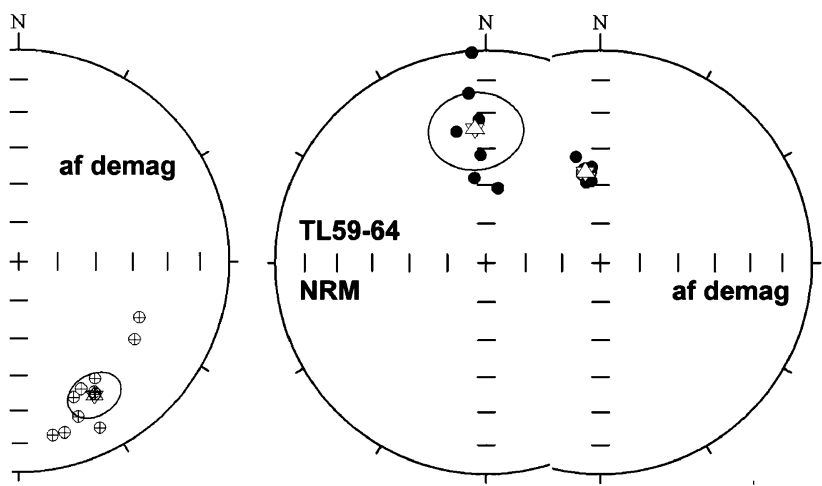

Fluvial deposit 


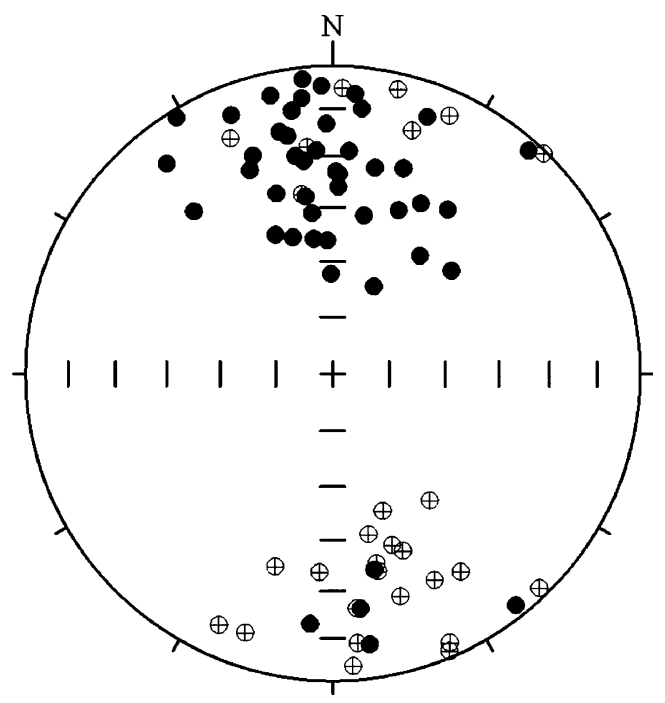

Fig. 7 Equal area plot of paleomagnetic directions, showing all accepted non-intermediate site-mean directions. Closed/open symbols define positive/negative inclinations

strata. Correlation between the combined sections MAL, SAN1, SAN2, TEP, SOM1, SOM2, TON and SAG yields a composite LMPS containing 14 reversals. These reversals are correlated to the age models of Cande and Kent (CK95; 1995). Considering the age constraints given by K-Ar and Ar-Ar geochronology (including their errors), this allows a correlation to (sub)chrons $6 \mathrm{Bn} .1 \mathrm{n}-5 \mathrm{Er}$, covering a time span of 3.97 Ma for the entire deposition of the Tepoztlán Formation (Fig. 8).

\section{Discussion}

Chronostratigraphic implications

Radiometric dating of dacitic lavas within the Tepoztlán Formation yielded ages between $24.1 \pm 3.6 \mathrm{Ma}$ and $19.8 \pm$ $0.8 \mathrm{Ma}$. Given the low potassium content of these rocks, it is difficult to say which of the K-Ar and Ar-Ar ages are more precise and reliable. However, combined with palaeomagnetic data, the chronostratigraphic study of the Tepoztlán Formation gives much better age constraints for its time of deposition. Considering the radiometric ages together with their errors, the best possible correlation of the composite LMPS is provided fitting to the CK95 GPTS. This correlates the sections to chrons $6 \mathrm{Bn} .1 \mathrm{n}-5 \mathrm{Er}$ in the early Miocene and encompasses a time of deposition between 22.8 and 18.8 Ma (22.8-22.2 Ma for MAL section, 22.8-21.3 Ma for SAN1 and SAN2 sections, 21.8-18.8 Ma for TEP section, 22.2-20.1 Ma for SOM1 and SOM2 sections, 21.8-20.5 Ma for TON section and 20.1-18.8 Ma for SAG section; see Fig. 6). Where individual sections overlap via lithostratigraphic correlation the polarity zones are coincident (e.g. SAN1 and SAN2, SOM1 and SOM2). This agreement of reversals in nearby, lithostratigraphically correlated sections reinforces the robustness of the local $(<500 \mathrm{~m})$ correlations and of the LMPS itself.

The resulting ages coincide with the time of the initial activity of the Transmexican Volcanic Belt as proposed by Ferrari et al. (2003) and García-Palomo et al. (2000). This study shows that the time of deposition of the Tepoztlán Formation fits into the time-frame provided by these authors; as such, the time of deposition of the Tepoztlán Formation can be defined more precisely. The formation of the San Nicolás Basaltic Andesite at 21.6 1.0 Ma (GarcíaPalomo 1998), underlying the Tepoztlán Formation in the Malinalco area, suggests a contemporaneous deposition of both formations within the study area. However, closer field relationships between both formations are yet to be studied. The post-depositional history of the Tepoztlán Formation is characterized by the emplacement of various dykes, yielding ages as young as $15.83 \pm 1.31 \mathrm{Ma}$, which corresponds to a period of plutonic to subvolcanic body emplacement and large fissure eruptions with widespread lava plateaus between the states of Nayarit and Veracruz (Ferrari and Rosas-Elguera 2000; Ferrari 2004; Ferrari et al. 2005), suggesting a genetic relationship between the younger volcanic activity and the dyke-emplacement.

\section{Sedimentary implications}

The stratigraphy of the Tepoztlán Formation obtained by this study shows that, due to a misinterpretation of certain deposits and a lack of time markers to correlate the stratigraphic sections, Haro-Estrop's (1985) subdivision of the formation needs revision. With the new age constraints and according to the dominant mode of deposition new subdivisions of the Tepoztlán Formation can now be proposed. The following lithostratigraphic names are suggested according to the type localities (Fig. 9): (1) a fluvial dominated lower unit (Malinalco Member; 22.8-22.2 Ma), (2) a volcanic dominated middle unit (San Andrés Member; 22.2-21.3 Ma) and (3) a mass flow dominated upper unit (Tepozteco Member; 21.3-18.8 Ma). Sediments near the SAG section that were formerly described by Haro-Estrop (1985) as part of the fluvial-laharic unit belonging to the middle part of the sedimentary sequence are now assigned to the youngest sediments within the succession.

The Malinalco Member of the succession (22.822.2 Ma), represented by sections SAN1 and MAL, shows a predominance of gravel bars and sandy channel fills, indicating deposition in a high-energy braided river system. The volcanic sandstones and conglomerates are a result of a sudden influx of voluminous pyroclastic debris derived from explosive eruptions. This is also seen in the few 


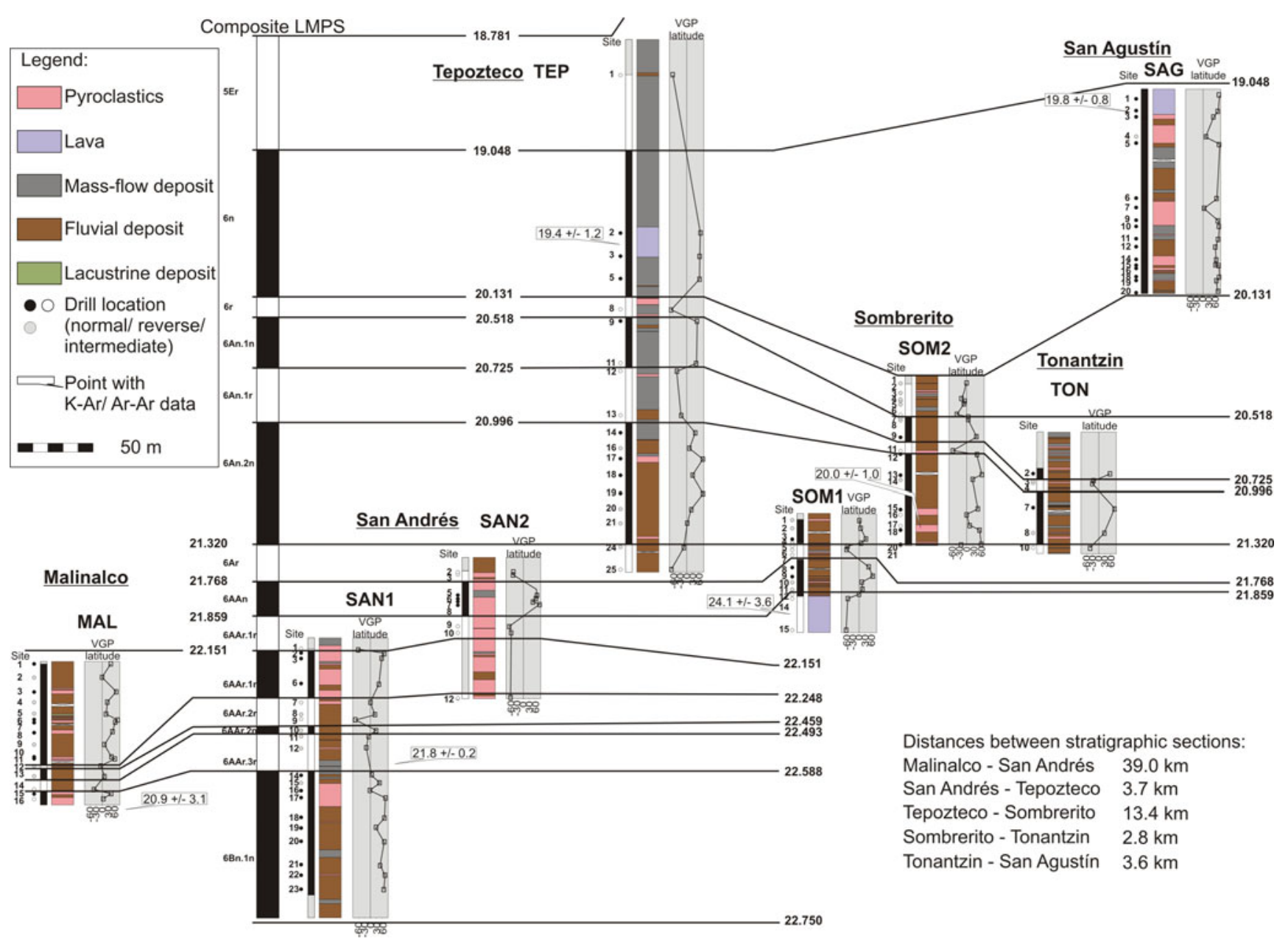

Fig. 8 Lithostratigraphic sections of the Tepoztlán Formation with paleomagnetic and radio-isotopic analysis results and magnetostratigraphic correlation to the geomagnetic polarity time scale of Cande and Kent (CK95; 1995)

Fig. 9 Chronostratigraphical correlation of the stratigraphic sections together with their predominant lithologies

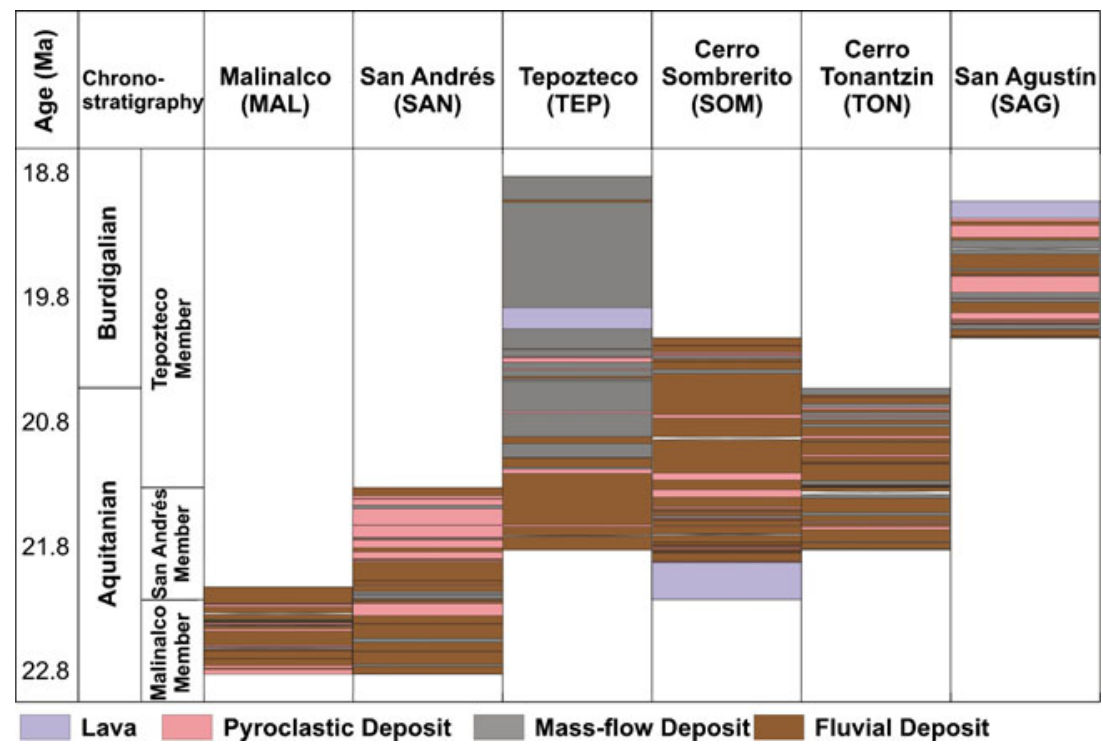


pyroclastic-flow and debris-flow deposits within this section. The prevalence of intermediate clasts and their relatively large sizes are consistent with a limited distance from the source via a high-energy transport system and thus suggest contemporaneous volcanism and sedimentation. In the San Andrés Member (22.2-21.3 Ma) a sudden increase in volcanic activity is noticed, associated with the deposition of massive ignimbrites in sections SAN1 and SAN2 and a thick lava flow in SOM1. The eruptions were vulcanian to subplinian events that generated few ash falls and relatively small pyroclastic density currents, probably extending not more than a few kilometers from their vents. Deposits from a block-and-ash flow in SAN1 and the lava in SOM1 point to proximal small vents. There are only minor amounts of primary volcaniclastics in MAL, which is dominated by thick sheets of gravel bars and sandy channel fills. However, lacustrine sediments found in MAL and near the village of Santo Domingo point to the development of lahar-dammed lakes after partial covering of the former river bed by volcanic activity.

Within the Tepozteco Member (21.3-18.8 Ma), a significant change from fluvial to prevailing mass-flow deposits can be noticed, especially within TEP. The debris-flow and hyperconcentrated-flow deposits in addition to high-energy, stream-dominated gravel bars are collectively lithofacies associations inherent to proximal alluvial fans (Mack and Rasmussen 1984). The transport distance for the clasts is in the order of kilometers, possibly less, as indicated by the clast size, angularity, the nature of the deposit (e.g. debris flow) and the local derivation of clasts. The debris-flow deposits seemingly reflect the increasing height of the volcanic edifices leading to steep slopes and increase of gravitational mass movement. This interpretation coincides with modern alluvial fans in volcanic settings (Vessel and Davies 1981; Pierson et al. 1990). The large-scale outcrop architecture of the Tepozteco Member together with the alternation of fluvial and gravitational transport modes can be interpreted as a large-scale alluvial fan, whose center was north of Tepoztlán. In contrast, the other sections (SOM1, SOM2, TON) were not or only partially affected by deposition from the alluvial fan, showing that they originated in a marginal setting. Sheet-flood deposits within these sections were interpreted to originate at the alluvial fan front, at the transition to the river system. The dominance of sandy to gravely sediments indicates a continuation of the braidedriver system in these areas, where the fluvial transport is occasionally disrupted by explosive eruptions in the near surroundings and high supply of pyroclastic materials. The deposition of SAG was influenced by another volcanic center very close to the section itself that is presently covered by lavas of the Chichinautzin Formation. The section is characterized by massive ignimbrites and an exposed lava dome emphasizing the closeness to the vent area.

\section{Conclusions}

The presented paleomagnetic and geochronological data are the basis for a first chronostratigraphy of the Lower Miocene volcaniclastic Tepoztlán Formation, producing a reliable magnetostratigraphy, which is correlated to the Geomagnetic Polarity Time Scale (GPTS) of Cande and Kent (1995). The time of deposition of the Tepoztlán Formation ranges between 22.8 and $18.8 \mathrm{Ma}(6 \mathrm{Bn} .1 \mathrm{n}-5 \mathrm{Er})$, implying that the studied formation represents the initial phase deposits of the TMVB. Reinforcing the robustness of the paleomagnetic and lithological correlations of nine individual sections, a detailed overall stratigraphic framework has been established. The results are consistent with the origin of the TMVB as stated by Ferrari et al. (2003) and Gómez-Tuena et al. (2007). Together with the San Nicolás Basaltic Andesite in Malinalco (García-Palomo et al. 2000), the Zitácuaro Volcanic Complex in Michoacán (Capra et al. 1997) and the volcanic rocks in the deepest part of the Mexico City Basin (Ferrari et al. 2003), the Tepoztlán Formation thus belongs to the few remnants of the ancestral TMVB.

In this study we suggested to subdivide the Tepoztlán Formation into three members according to the dominant mode of deposition: (1) the fluvial dominated Malinalco Member (22.8-22.2 Ma), (2) the volcanic dominated San Andrés Member (22.2-21.3 Ma) and (3) the mass flow dominated Tepozteco Member (21.3-18.8 Ma). The central part of the study area (SAN1, SAN2, TEP) and SAG was strongly affected by the deposition from a volcanically induced alluvial fan, which implies that the main build-up phase of the TF took place in that time interval. Sections MAL, SOM1, SOM2 and TON are, in contrast, characterized by the deposition in the fringe areas of the alluvial fans and are dominated by braided-river sediments.

Acknowledgements This study is a part of the Ph.D. thesis of the first author, which was part of a cooperative project between the Technische Universität Darmstadt, Germany and the Universidad Nacional Autónoma de México, Mexico. The study was funded by the Deutsche Forschungsgemeinschaft (DFG), project HI 643/ 5-1. I.S. Torres-Alvarado thanks PAPIIT-UNAM (project IN 108408) for additional financial support. H. Böhnel acknowledges support by Conacyt (grant 46213). We are grateful to the entire sedimentology team of the Technische Universität Darmstadt, Germany, especially the students Andreas Hechler, Nils Michelsen, Gabino TunonVettermann, Nora Schwab, Christian Bär, Jasaman Faridfar, Steffen Lehmann and Kristian Cizmezcia who assisted in the field. Furthermore, we thank José Luis Rodríguez Vargas, Iván Barajas Gea and Gildardo González Naranjo for assisting in the laboratory of the Centro de Geociencias, Querétaro. Holger Scheibner (Technische Universität Darmstadt) is thanked for the preparation of thin sections and cutting of the rock samples. Laura Roberts, Stephan Kempe and Sukanya Lenhardt helped to improve the style of this contribution. We are indebted to John Stix, Hugo Delgado Granados, Emilio Herrero and an anonymous reviewer for their thorough review of the manuscript and many helpful critical remarks and suggestions. 


\section{References}

Allen SR, Stadlbauer E, Keller J (1999) Stratigraphy of the Kos Plateau Tuff: product of a major Quaternary explosive rhyolithic eruption in the eastern Aegean, Greece. Int J Earth Sci 88:132-156

Ávila-Bravo V (1998) Cartografía geológica y estratigrafía del grupo Chichinautzin, en el área de Tepoztlán, Morelos. Tesis Licenciatura (Ingeniero Geólogo), Facultad de Ingeniería, UNAM

Barberà X, Cabrera L, Marzo M, Parés JM, Agustí J (2001) A complete terrestrial Oligocene magnetobiostratigraphy from the Ebro Basin, Spain. Earth Planet Sci Lett 187:1-16

Cande SC, Kent DV (1995) Revised calibration of the geomagnetic polarity timescale for the Late Cretaceous and Cenozoic. J Geophys Res 100:6093-6095

Cantagrel J, Robin C (1979) K-Ar dating on eastern Mexican volcanic rocks-Relations between the andesitic and alkaline provinces. J Volcanol Geotherm Res 5:99-114

Capra L, Macías JL (2000) Pleistocene cohesive debris flows at Nevado de Toluca Volcano, central Mexico. J Volcanol Geotherm Res 102:149-167

Capra L, Macías J, Garduno V (1997) The Zitácuaro Volcanic Complex, Michoacán, México: magmatic and eruptive history of a resurgent caldera. Geofís Int 36:161-179

Capra L, Macías JL, Scott KM, Abrams M, Garduno-Monroy VH (2002) Debris avalanches and debris flows transformed from collapses in the Trans-Mexican Volcanic Belt, Mexico-Behavior and implications for hazard assessment. J Volcanol Geotherm Res 113:81-110

Cas RAF, Wright JV (1987) Volcanic successions-modern an ancient. Allen \& Unwin, London

De Cserna Z, Fries C (1981) The volcanic centre of Zempoala, Central Mexico. Geofís Int 34:98-117

De Cserna Z, De La Fuente-Duch M, Palacios-Nieto M, Triay L, Mitre-Salazar LM, Mota-Palomino R (1988) Estructura geológica, gravimetría, sismicidad y relaciones neotectónicas regionales de la cuenca de México. Bol Inst Geol UNAM 104:1-71

Demant A (1978) Características del eje neovolcánico Transmexicano y sus problemas de interpretacíon. Rev Inst Geol 2:172-187

Dunham RJ (1962) Classification of carbonate rocks according to depositional texture. In: Ham WE (ed) Classification of carbonate rocks. Am Assoc Petrol Geol Mem 1:108-121

Ferrari L (2004) Slab detachment control on mafic volcanic pulse and mantle heterogeneity in central Mexico. Geology 32:77-80

Ferrari L, Rosas-Elguera J (2000) Late Miocene to Quaternary extension at the northern boundary of the Jalisco block, western Mexico: the Tepic-Zacoalco rift revised. In: Auirre-Díaz G, Delgado-Granados H, Stock J (eds) Cenozoic tectonics and volcanism of Mexico. Geol Soc Am Spec Pap 334:42-64

Ferrari L, Lopez-Martinez M, Aguirre-Díaz G, Carrasco-Núñez G (1999) Space-time patterns of Cenozoic arc volcanism in Central Mexico: from the Sierra Madre Occidental to the Mexican volcanic belt. Geology 27:303-306

Ferrari L, Vaggelli G, Petrone C, Manetti P, Conticelli S (2000) Late Miocene volcanism and intra-arc tectonics during the early development of the Trans-Mexican Volcanic Belt. Tectonophysics 318:161-185

Ferrari L, López-Martínez M, González-Cervantes N, Jacobo-Albarrán J, Hernández-Bernal M (2003) Volcanic record and age of formation of the Mexico City basin. Reunión Annual de la Unión Geofísica Mexicana 23:120

Ferrari L, Tagami T, Eguchi M, Orozco-Esquivel M, Petrone C, Jacobo-Albarrán J, López-Martínez M (2005) Geology, geochronology and tectonic setting of late Cenozoic volcanism along the southwestern Gulf of Mexico: the Eastern Alkaline Province revisited. J Volcanol Geotherm Res 146:284-306

Fisher R (1953) Dispersion on a sphere. Proc Royal Soc London A, Math Phys Sci 217(1130):295-305
Fisher RV, Schmincke H-U (1984) Pyroclastic rocks. Springer Verlag, Berlin

Fries C (1960) Geología del Estado de Morelos y de partes adyacentes de México y Guerrero, región central meridional de México. Bol Inst Geol UNAM 60:1-236

Fuhrmann U, Lippolt HJ, Hess JC (1987) Examination of some proposed K-Ar standards: ${ }^{40} \mathrm{Ar} /{ }^{\beta 9} \mathrm{Ar}$ analyses and conventional K-Ar-Data. Chem Geol 66:41-51

García-Palomo A (1998) Evolucion estructural en las inmediaciones del Volcan Nevado de Toluca, Edo. De Mexico. MSc Thesis, UACP y P del CCH, UNAM, Mexico

García-Palomo A, Macías JL, Garduno VH (2000) Miocene to recent structural evolution of the Nevado de Toluca volcano region, Central Mexico. Tectonophysics 318:281-302

García-Palomo A, Macías JL, Arce JL, Capra L, Garduño VH, Espíndola JM (2002) Geology of Nevado de Toluca Volcano and surrounding areas, central Mexico. Geol Soc Am Map Chart Ser MCH089, pp 1-26

Gómez-Tuena A, Orozco-Esquivel, Ma T, Ferrari L (2007) Igneous petrogenesis of the Trans-Mexican Volcanic Belt. In: AlanizÁlvarez SA, Nieto-Samaniego ÁF (eds) Geology of México: celebrating the Centenary of the Geological Society of México. Geol Soc Am Spec Pap 422:129-181

Haro-Estrop J (1985) Estudio sedimentologico de la Porcion oriental de la Formación Tepoztlán, Morelos. Tesis Licenciatura (Ingeniero Geólogo), Facultad de Ingeniera, UNAM

Heinrichs H, Herrmann AG (1990) Praktikum der analytischen Geochemie. Springer Verlag, Heidelberg

Kirshvink JL (1983) The least-squares line and plane and the analysis of paleomagnetic data. Geophys J Roy Astron Soc 75:593-621

Lenhardt N (2004) Sedimentologische und palynologische Untersuchungen im Bereich der Typlokalität der vulkanoklastischen Formacíon Tepoztlán (Morelos, Mexico). MSc Thesis, TU Darmstadt, Germany

Lenhardt N (2009) Sedimentology, stratigraphy and palynology of the volcaniclastic Tepoztlán Formation (Lower Miocene, Central Mexico): implications for the evolution of the Transmexican Volcanic Belt. PhD Thesis, TU Darmstadt, Germany

Mack GH, Rasmussen KA (1984) Alluvial-fan sedimentation of the Cutler Formation (Permo-Pennsylvanian), near Gateway, Colorado. Geol Soc Am Bull 95:109-116

Márquez A, Verma S, Anguita F, Oyarzun R, Brandle J (1999) Tectonics and volcanism of Sierra Chichinautzin: extension at the front of the central Transmexican Volcanic Belt. J Volcanol Geotherm Res 93:125-150

McArthur AN, Cas RAF, Orton GJ (1998) Distribution and significance of crystalline, perlitic and vesicular textures in the Ordovician Garth Tuff (Wales). Bull Volcanol 60:260-285

McDougall I, Harrison TM (1999) Geochronology and thermochronology by the ${ }^{40} \mathrm{Ar} /{ }^{39} \mathrm{Ar}$ method, 2nd edn. Oxford University Press, New York

McPhie J, Doyle M, Allen R (1993) Volcanic textures - a guide to the interpretation of textures in volcanic rocks. Centre for Ore Deposit and Exploration Studies, University of Tasmania

Merrill RT, McElhinny MW, McFadden PL (1998) The magnetic field of the earth-Paleomagnetism, the core, and the deep mantle. International Geophysics series 63. Academic Press, New York

Mooser F (1972) The Mexican Volcanic Belt structure and tectonics. Geofis Int 12:55-70

Nixon G, Demant A, Armstrong R, Harakal J (1987) K-Ar and geologic data bearing on the age and evolution of the TransMexican Volcanic Belt. Geofís Int 26:109-158

Ordónez E (1938) Tepoztlán, Estado de Morelos. Soc Geol Mexicana Bol:3-24

Pasquaré G, Ferrari L, Garduño V, Tibaldi A, Vezzoli L (1991) Geology of the central sector of the Mexican Volcani Belt, States 
of Guanajuato and Michoacan. Geol Soc Am Map Charts Ser MCH072, scale 1:300,000, 1 sheet, pp 1-22

Pierson TC, Janda RJ, Thouret JC, Borerro CA (1990) Perturbation and melting of snow and ice by the 13 November 1985 eruption of Nevado del Ruiz, Colombia, and consequent mobilization, flow, and deposition of lahars. J Volcanol Geotherm Res 41:17-66

Riggs N, Carrasco-Núnez G (2004) Evolution of a complex isolated dome system, Cerro Pizarro, central México. Bull Volcanol 66:322-335

Roddick JC (1978) The application of isochron diagrams in ${ }^{40} \mathrm{Ar}-{ }^{39} \mathrm{Ar}$ dating: a discussion. Earth Planet Sci Lett 41:233-244

Schumacher E (1975) Herstellung von 99, 9997\% 38Ar für die ${ }^{40} \mathrm{~K} /{ }^{40} \mathrm{Ar}$ geochronologie. Geochron Chimica 24:441-442

Siebe C, Macías JL (2004) Volcanic hazards in the Mexico City metropolitan area from eruptions at Popocatépetl, Nevado de Toluca, and Jocotitlán stratovolcanoes and monogenetic scoria cones in the Sierra Chichinautzin Volcanic Field. Penrose Field Guide: Penrose Field Guide 1, pp 1-77

Siebe C, Rodríguez-Lara V, Schaaf P, Abrams M (2004) Geochemistry, Sr-Nd isotope composition, and tectonic setting of Holocene Pelado, Guespalapa and Chichinautzin scoria cones, south of Mexico City. J Volcanol Geotherm Res 130:197-226
Steiger RH, Jäger E (1977) Subcommission on geochronology: convention on the use of decay constants in geo- and cosmochronology. Earth Planet Sci Lett 36:359-362

Verma S (2000) Geochemistry of the subducting Cocos plate and the origin of subduction-unrelated mafic volcanism at the front of the central Mexican Volcanic Belt. In: Delgado-Granados H, AguirreDíaz G, Stock J (eds) Cenozoic tectonics and volcanism of Mexico. Geol Soc Am Spec Pap 334:1-28

Vessel RD, Davies DK (1981) Nonmarine sedimentation in an active fore arc basin. In: Ethridge FG, Flores RM (eds) Nonmarine depositional environments: models for exploration. Soc Econ Paleontol Mineral Spec Pub 31:34-45

Wemmer K (1991) K/Ar-Altersdatierungsmöglichkeiten für retrograde deformationsprozesse im spröden und duktilen Bereich-Beispiele aus der KTB-Vorbohrung (Oberpfalz) und dem Bereich der Insubrischen Linie (N-Italien). Göttinger Arb Geol Paläont 51:1-61

Wendt I, Carl C (1991) The statistical distribution of the mean squared weighted deviation. Chem Geol 86:275-285

Zijderveld JDA (1967) Demagnetization of rocks: analysis of results. In: Collinson DW, Creer KM, Runcorn SK (eds) Methods in palaeomagnetism. Elsevier, Amsterdam, pp 254-286 